\title{
Effect of soil amendments on phytoextraction potential of Brassica juncea growing on sewage sludge
}

\author{
G. Dede $\cdot$ S. Ozdemir $\cdot$ O. Hulusi Dede
}

Received: 23 March 2011/Revised: 16 June 2011/ Accepted: 28 December 2011/Published online: 11 April 2012

(c) CEERS, IAU 2012

\begin{abstract}
A pot experiment was conducted to investigate the influence of elemental sulfur, gypsum and chelating agent (Ethylenediaminetetraacetic acid) on copper, zinc, nickel, cadmium, chromium and lead uptake by Brassica juncea from sewage sludge. Addition of sulphur acidified the sludge, which caused the $\mathrm{pH}$ decrease to 5.4 with an initial $\mathrm{pH}$ 6.7. The shoot and root biomass were increased with sulfur addition, while decreased with Ethylenediaminetetraacetic acid addition. Applications of Ethylenediaminetetraacetic acid and sulfur resulted in a considerable increase in copper and lead concentrations in the plant. The highest root concentration of copper obtained to be $110 \mathrm{mg} / \mathrm{kg} \mathrm{dw}$ at Ethylenediaminetetraacetic acid treatment. For sulfur treatment, lead concentrations in shoots indicated almost high concentrations $77 \mathrm{mg} / \mathrm{kg}$, about twofold increases relative to roots $(34 \mathrm{mg} / \mathrm{kg})$. The Transportation Index of all studied metals were quite low (TI $<0.5$ ), whereas the Bioaccumulation Factor values were much higher, varied from 0.01 to 9.67 . Furthermore, the plant showed better Bioaccumulation Factor for copper and lead metals in both shoot and root. The efficiency to remove copper and lead from sludge is high in this plant. As a result, elemental sulfur will be effective amendment for phytoextraction of heavy metals from sewage sludge.
\end{abstract}

Keywords Biosolid Ethylenediaminetetraacetic acid . Elemental sulfur · Gypsum - Heavy metal removal . Hyperaccumulator plant

G. Dede $(\bowtie) \cdot S$. Ozdemir · O. Hulusi Dede

Department of Environmental Engineering, Engineering Faculty, Sakarya University, 54187 Adapazari, Sakarya, Turkey

e-mail: gulgunk@sakarya.edu.tr

\section{Introduction}

The application of sewage sludge in agriculture is generally considered the best option of management, because it offers the possibility of recycling plant nutrients, provides organic material to the soil, and improves the soil's aggregate stability, porosity and water infiltration rate (Torri and Lavado 2008). However, the presence of high concentrations of toxic metals in sludge poses a constraint on the application of this sludge's to the agricultural land. Therefore, heavy metal removal from sewage sludge is considerable to minimize prospective risks during and after the application. Unfortunately, existing remediation methods for heavy metal removal from sludge or soils are expensive and disruptive (Pogrzeba et al. 2004). In recent years, efforts have focused on the remediation strategies that are less expensive and less destructive than current approaches (Singh and Sinha 2005; Gupta and Sinha 2007a, b; Pogrzeba et al. 2004; Xiaomei et al. 2005; Samake et al. 2003). Phytoremediation, defined as the use of plants to remove pollutants from the environment, which is a promising technology for remediation of contaminated soils and perhaps for the removal of metals from sludge. Unfortunately, the success of phytoremediation depends on solubility of heavy metals and ability of plant to uptake and translocate the heavy metals to the upper parts (Turgut et al. 2004). Several chelating agents, such as CDTA, DTPA, EDDHA, EDDS, EDTA, EGTA, HEDTA and NTA have been studied for their ability to dissolve metals and enhance the uptake of metals by plants. However, these chemicals have limitations due to their negative effects on plant and soil properties (Kaplan et al. 2005; Wenger et al. 2002; Kayser et al. 2000; Catherine et al. 2006; Cui et al. 2004a, b; Wang et al. 2006; Robinson et al. 1999). 
The use of natural elements such as $\mathrm{S}$ has, therefore, been suggested for alleviation of these constraints and for soil acidification to increase the solubility of metals in contaminated soils (Kayser et al. 2001; Cui et al. 2004a, b). Thus, the objectives of the study were to determine the heavy metal removal of Brassica juncea from sewage sludge and to evaluate the effect of soil amendments such as $\mathrm{S}$ and gypsum on the uptake and translocation of heavy metals. EDTA was used as the model chelator to examine enhanced metal mobilization and distribution of heavy metals within the plant tissues. The experiment was carried out in the climatic conditions of Sakarya, Turkey. The experiment was carried out from March 10, 2009 to March $10,2010$.

\section{Materials and methods}

\section{Sewage sludge characteristics}

Raw, undigested and dewatered sewage sludge (20\% DW) was obtained from Adapazari Municipal Waste Water Treatment Plant. The physicochemical properties of the sludge were: $\mathrm{pH} 6.7$, EC $1998 \mu \mathrm{S} / \mathrm{cm}$, organic matter content $54 \%$, total N $4.10 \%$, P $3.15 \%$, K $0.12 \%$, CEC $8.53 \mathrm{cmol}(+) / \mathrm{kg}$, organic carbon $31.21 \%, \mathrm{C} / \mathrm{N} 7.61$. Heavy metal content of the sewage sludge was Cu $19 \mathrm{mg} / \mathrm{kg}$, Zn 1435 mg/kg, Cr 243 mg/kg, Ni 79 mg/kg, Pb 34 mg/kg, $\mathrm{Cd} 3 \mathrm{mg} / \mathrm{kg}$.

\section{Plant and cultivation}

B. juncea seeds were sown at a rate of six in the plastic pots containing $4.5 \mathrm{~kg}$ of raw sewage sludge and thinned to three individuals in each pot, 1 week after germination. Pots were placed in an open-air condition at an average temperature of $20-25{ }^{\circ} \mathrm{C}$. The tap water was provided to the pots to keep the top layer moist and avoid leaking from the pots. Plant was harvested after 1 year of growing periods.

\section{Experimental design and treatments}

The experiment was carried out according to the randomized plot design with four replicates. At the beginning of the experiments, different amounts of elemental sulfur (S) $(0,78,156,312,625 \mathrm{mmol} / \mathrm{kg})$ were used to adjust sludge $\mathrm{pH}$ to desired levels based on a preliminary incubation experiment. Sludge $\mathrm{pH}$ was monitored periodically by taking $10 \mathrm{~g}$ soil and measuring $\mathrm{pH}$. Changes in sludge $\mathrm{pH}$ under different treatments of $\mathrm{S}$ were shown in Table 1 . Sludge was thoroughly mixed every day to ensure equal distribution of $\mathrm{S}$ and to accelerate the $\mathrm{S}$ oxidation process.
Table 1 Changes in sludge $\mathrm{pH}$ under different treatments of $\mathrm{S}$

\begin{tabular}{llllll}
\hline Treatment & 16 days & 28 days & 36 days & 50 days & 65 days \\
\hline $\mathrm{S}_{0}$ & 6.7 & 6.9 & 6.6 & 5.6 & 6.6 \\
$\mathrm{~S}_{0.25}$ & 6.7 & 6.1 & 6.1 & 5.4 & 6.1 \\
$\mathrm{~S}_{0.5}$ & 6.5 & 6.0 & 6.0 & 5.4 & 5.7 \\
$\mathrm{~S}_{1}$ & 6.4 & 5.9 & 5.8 & 5.4 & 5.4 \\
$\mathrm{~S}_{2}$ & 6.6 & 5.6 & 5.0 & 3.0 & 2.7 \\
\hline
\end{tabular}

Incubation was terminated when $\mathrm{pH}$ did not change for 3 consecutive weeks. It took 9 weeks to reach the final $\mathrm{pH}$ (5.4) for S amendment (Table 1). Four different applications, which were the equivalents of elemental, finely ground sulfur at a rate of $312 \mathrm{mmol} / \mathrm{kg}$ (fresh weight) of sludge (T1); gypsum applied at $1.8 \mathrm{~g}$ per pot in consideration of 1 ton per hectare (T2); EDTA applied at a rate of $5 \mathrm{mmol} / \mathrm{kg}$ (T3) and control (T4).

Sampling and analysis

Oven dried $\left(70{ }^{\circ} \mathrm{C}\right)$, ground and sieved with $2 \mathrm{~mm}$ mesh size sludge samples were used in the analysis. Sludge $\mathrm{pH}$ was measured with a $\mathrm{pH}-$ meter at the 1:5 (w/v) ratio of sludge water suspension (Kalra and Maynard 1991). The electrical conductivity (EC) was measured with an EC electrode at the 1:5 (w/v) sludge water suspension (Kalra and Maynard 1991). Organic matter (OM) and organic carbon (\%) were measured according to Walkley and Black method (Ryan et al. 2001). Total N was determined by the Kjeldahl method (Kalra and Maynard 1991). Phosphorus was measured spectrophotometrically according to Bingham method (Pierzynski 2000) and potassium was obtained at ICP-MS (Perkin Emler, Optima 2100 DV) by employing ammonium acetate method (Ryan et al. 2001). Cation exchange capacity was obtained according to $\mathrm{BaCl}_{2}$ extraction method (Ross 2001). Sludge samples $(\sim 250 \mathrm{mg})$ were digested in a Microwave Digestion System (MWS-3, DAP 60S) using $6 \mathrm{ml}$ of $\mathrm{HNO}_{3}(65 \%), 1 \mathrm{ml}$ of $\mathrm{H}_{2} \mathrm{O}_{2}(30 \%)$ acid mixture and then heavy metal contents were determined with an ICPMS (Perkin Emler, Optima 2100 DV).

After harvest of the plant materials, plants were washed with tap water, rinsed with deionized water and finally blotted dry. Plants were separated in roots and shoot with a stainless steel scissor and then oven-dried at $78{ }^{\circ} \mathrm{C}$ to constant weight. Dry weights of the shoots and roots were measured and then samples were ground into fine powder, sieved through $2 \mathrm{~mm}$ sieve (Kalra and Maynard 1991). Samples $(\sim 250 \mathrm{mg})$ were digested in a microwave oven (MWS-3, DAP 60S) using $6 \mathrm{ml}$ of $\mathrm{HNO}_{3}(65 \%), 1 \mathrm{ml}$ of $\mathrm{H}_{2} \mathrm{O}_{2}(30 \%)$ acid mixture and then analyzed for heavy metal concentrations with an ICP-MS (Perkin Emler, Optima 2100 DV) (Kalra and Maynard 1991). 
Data analysis

Two indicators were calculated to evaluate the plant for phytoextraction purposes. The Bioaccumulation Factor (BF) was calculated for root and shoot by dividing the trace-element concentration in plant tissues $(\mathrm{mg} / \mathrm{kg})$ at harvest by the initial concentration of the element in the sludge $(\mathrm{mg} / \mathrm{kg})$ in which the plant grew. The Transportation Index $\left(\mathrm{TI}_{\text {shoots }}=\mathrm{C}_{\text {roots }}\right.$ ) was calculated for total plant from the compartment concentrations of heavy metals to evaluate the plant for phytoextraction purposes, and in particular, the plant ability to translocate the heavy metals from roots to the harvestable aerial part (Ghosh and Singh 2005).

Measured data for the sewage sludge and plant were analyzed statistically using two ways ANOVA analysis procedure to compare the treatment effects on heavy metal removal of plant. Treatment means were compared with a least significant differences test (LSD) at $p<0.05$.

\section{Results and discussion}

\section{Sludge characteristics after harvesting}

From the obtained results, agronomic characteristics of sewage sludge, such as $\mathrm{pH}, \mathrm{EC}, \mathrm{CEC}$ and organic matter content, were in acceptable range and all favorable for subsequent plant growth (McFarland 2000). Additional fertility characteristics, such as NPK levels, organic carbon and $\mathrm{C} / \mathrm{N}$ ratio, were also fairly consistent.

The total concentrations of $\mathrm{Cd}, \mathrm{Cr}, \mathrm{Cu}, \mathrm{Ni}, \mathrm{Pb}$ and $\mathrm{Zn}$ in the sewage sludge were much lower than the limits recommended by the Turkish Soil Pollution Control Regulations for agricultural usage. On this account, sewage sludge was classified as an excellent amendment for agricultural use. Unfortunately, sludge generally contains excessive $\mathrm{Cd}$, $\mathrm{Ni}$ and $\mathrm{Zn}$ compared to the European Union standards; therefore, long-term and unrestricted applications of sludge have led to an increase in soil heavy metal content. Thus, removal of heavy metal from sewage sludge by hyperaccumulator plants could be a promising technology.

Heavy metal content of sewage sludge after harvesting was obtained as $3 \mathrm{mg} / \mathrm{kg} \mathrm{Cu}, 1100 \mathrm{mg} \mathrm{kg}^{-1} \mathrm{Zn}, 85 \mathrm{mg} / \mathrm{kg}$ $\mathrm{Cr}, 20 \mathrm{mg} / \mathrm{kg} \mathrm{Ni}, 21 \mathrm{mg} / \mathrm{kg} \mathrm{Pb}$, and $2 \mathrm{mg} / \mathrm{kg} \mathrm{Cd}$. Obtained results showed that $65-70 \%$ of the heavy metal was removed by $B$. juncea. $30-35 \%$ of the residual metal content was remained at sludge.

Sludge $\mathrm{pH}$ decreased in all the treatments with application of S compared to the control. Robinson et al. (1999) reported that $5 \mathrm{~g}$ of elemental, finely ground sulfur per kilogram of soil was added with an initial soil pH 6.9 and the soil $\mathrm{pH}$ decreased to 5.5 within 15 weeks. Kayser et al.
(2000) reported that adding $36 \mathrm{~mol} \mathrm{~S} \mathrm{~m}^{-2}$ to the soil led to a decrease in soil $\mathrm{pH}$ from 7.2 to 6.9. In the present study, adding $\mathrm{S}$ also acidified the sludge, which caused the $\mathrm{pH}$ decrease to 5.4 with an initial pH 6.7 within 9 week just as in the incubation experiments (Table 1).

Plant yield

Shoot and root biomass of $B$. juncea influenced by different treatments were shown in Fig. 1. Treatments by plant interaction had significant effects on yield of $B$. juncea $(p<0.001)$. Compared to the control, the growth and aboveground biomass of $B$. juncea were significantly enhanced by $\mathrm{S}$ addition. Plant dry biomass ranged from 35 to $43 \mathrm{~g} /$ pot and highest yield obtained at the $\mathrm{S}$ application (lowest pH treatment) (Fig. 1). Cui et al. (2004a, b) reported that root and shoot weight in tested plants significantly decreased with $\mathrm{S}$ application and also Kayser et al. (2001) reported that shoot weight in some plants did not change significantly with $\mathrm{S}$ application. However, in the present study, application of $S$ increased the plant biomass. One of the possibilities was that the decrease of sludge $\mathrm{pH}$ may cause an increase in the solubility and bioavailability of the nutrients. However, another reason might be that different plants have different sensitivity to the toxicity of amendments. Nonetheless, application of EDTA chemical to sludge causes a decrease on the plant yield (Fig. 1). EDTA applied 2 weeks before harvest and both root and shoot yields were obtained lower compared to control, and the effect was more pronounced on the shoots as obtained at Jiang et al. (2003). At root biomasses, there were no significant differences between yields of EDTA treated and control plants, and root and shoot yields of all plants declined with application of EDTA (Fig. 1). At the gypsum treatment, no significant differences in biomasses were observed to control application.

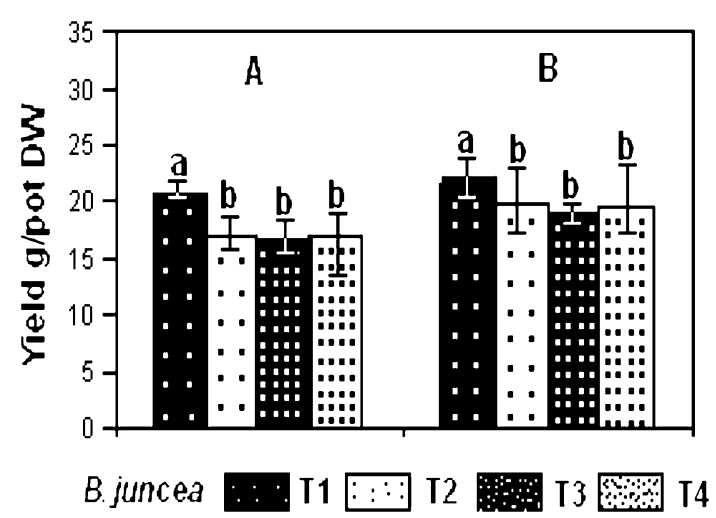

Fig. 1 Shoot and root biomass of B. juncea influenced by different treatments: a root and b shoot (T1: sulfur, T2: gypsum, T3: EDTA, T4: control treatments) (Vertical bars indicate standard deviation, $n=4)$ 
Heavy metal accumulation in plant tissues

Heavy metal concentrations $(\mathrm{mg} / \mathrm{kg} \mathrm{dw})$ of $B$. juncea at different treatments were shown in Fig. 2. Overall, the total metal accumulation (sum of the metal in the root and shoot) in plant was in the order of $\mathrm{Zn}>\mathrm{Pb}>\mathrm{Cu}>$ $\mathrm{Cr}>\mathrm{Ni}>\mathrm{Cd}$, which varied from one part to another (Fig. 2).

The highest zinc concentration was obtained $681 \mathrm{mg} / \mathrm{kg}$ root dw at EDTA treatment, nearly threefold higher than the concentrations in shoots $(251 \mathrm{mg} / \mathrm{kg} \mathrm{dw})$. The second was obtained at S treatment as $379 \mathrm{mg} / \mathrm{kg}$ root dw (Fig. 2). Applications of EDTA and $\mathrm{S}$ resulted in a considerable increase in the $\mathrm{Cu}$ and $\mathrm{Pb}$ concentrations in the plant. The concentration of $\mathrm{Cu}$ in roots reached $110 \mathrm{mg} / \mathrm{kg} \mathrm{dw}$ at EDTA treatment (Fig. 2). The concentration of $\mathrm{Cu}$ in the sewage sludge is $19 \mathrm{mg} / \mathrm{kg}$, and the obtained root $\mathrm{Cu}$ concentration is 8 times higher than this. The second highest $\mathrm{Cu}$ accumulation was obtained at $\mathrm{S}$ treatment as $93 \mathrm{mg} / \mathrm{kg}$ root dw (Fig. 2). Plant samples exhibit $\mathrm{Cu}$ concentrations higher than $20 \mathrm{mg} / \mathrm{kg}$, considered by KabataPendias (2001), as the limit for toxicity. But generally, the concentration of $\mathrm{Cu}$ in shoots is lower than in roots. As has been observed for all tested metals except for $\mathrm{Pb}, \mathrm{Cu}$ concentrated in the roots and was not moved to the upper part of the plant.

It is well known that $\mathrm{Pb}$ is an immobile metal in soil, since it readily forms a precipitate with a low aqueous solubility within the soil matrix, and in many cases it is not readily bioavailable. In addition, many plants retain $\mathrm{Pb}$ in their roots via sorption and precipitation with only minimal transport to the aboveground harvestable plant portions (Cui et al. 2004a, b). In the present study, at the EDTA treatment, the $\mathrm{Pb}$ concentration in shoots was as obtained $82 \mathrm{mg} / \mathrm{kg}$, representing about twofold increases relative to the roots $(42 \mathrm{mg} / \mathrm{kg})$. For the $\mathrm{S}$ treatment, the $\mathrm{Pb}$ concentrations in shoots were representing almost high concentrations, $77 \mathrm{mg} / \mathrm{kg}$, about twofold increases relative to the roots $(34 \mathrm{mg} / \mathrm{kg})$. The concentration of $\mathrm{Pb}$ in sewage sludge is $34 \mathrm{mg} / \mathrm{kg}$, while $B$. juncea exhibit $\mathrm{Pb}$ concentration is well above this value, and therefore, tested plant appears to accumulate $\mathrm{Pb}$ in the tissues (Fig. 2).

The best results for $\mathrm{Ni}$ phytoextraction were obtained at roots $(66 \mathrm{mg} / \mathrm{kg})$ for EDTA treatment followed by the shoots $(12 \mathrm{mg} / \mathrm{kg})$. The highest concentration of $\mathrm{Cd}$ was found in roots $(3 \mathrm{mg} / \mathrm{kg})$ despite the concentration of $\mathrm{Cd}$ in the plant tissues was below the sewage sludge $\mathrm{Cd}$ concentration level ( $3 \mathrm{mg} / \mathrm{kg}$ ). The highest concentration of $\mathrm{Cr}$ was found in roots $(170 \mathrm{mg} / \mathrm{kg})$. Almost, obtained $\mathrm{Cr}$ concentrations were below the sewage sludge $\mathrm{Cr}$ concentrations $(243 \mathrm{mg} / \mathrm{kg})$ as obtained $\mathrm{Cd}$ concentrations (Fig. 2).

Bioaccumulation factor (BF) and Transportation index (TI) from sludge to plant were shown in Table 2. Translocation of metals was restricted from root to shoot, as among the plant tested; the concentrations of heavy metals in roots were higher $(p<0.01)$ than the shoots. Unfortunately, a primary concern for plants grown in sewage sludge is the accumulation of metals in aboveground tissues (Xiaomel et al. 2005). Therefore, from the obtained $\mathrm{BF}$ and TI values, plant did not hyperaccumulate zinc in the tissues and did not translate to the upper parts $(\mathrm{BF}<1$,
Fig. 2 Heavy metal concentrations $\left(\mathrm{mg} \mathrm{kg}^{-1} \mathrm{dw}\right)$ of $B$. juncea at different treatments (T1: sulfur, T2: gypsum, T3: EDTA, T4: control treatments) (Vertical bars indicate standard deviation, $n=4$ )
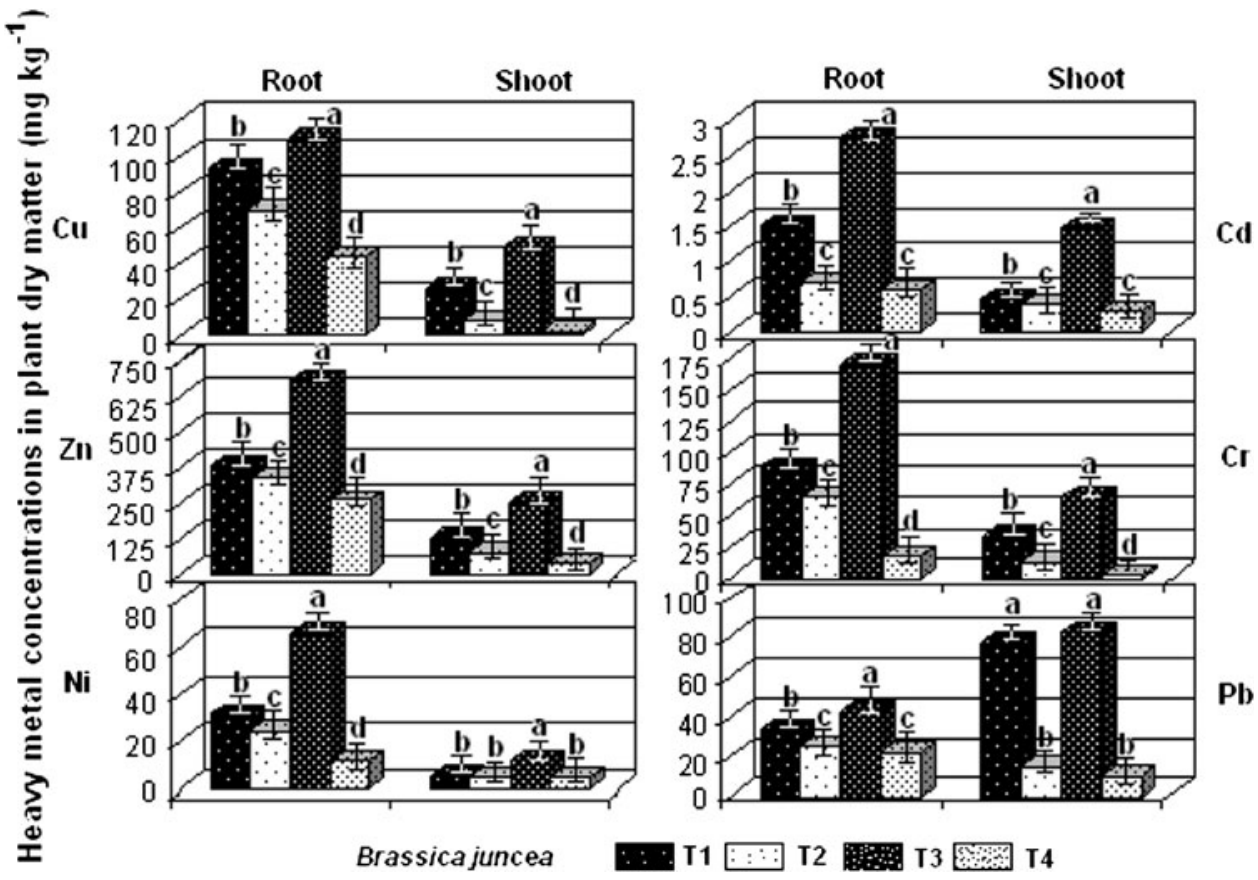
Table 2 Bioaccumulation factor (BF) and Transportation index (TI) from sludge to plant

\begin{tabular}{|c|c|c|c|c|c|c|c|c|c|c|c|c|}
\hline \multirow[t]{2}{*}{ Treatments } & \multicolumn{2}{|l|}{$\mathrm{Cu}$} & \multicolumn{2}{|l|}{$\mathrm{Zn}$} & \multicolumn{2}{|l|}{$\mathrm{Ni}$} & \multicolumn{2}{|l|}{$\mathrm{Cd}$} & \multicolumn{2}{|l|}{$\mathrm{Cr}$} & \multicolumn{2}{|l|}{$\mathrm{Pb}$} \\
\hline & Root & Shoot & Root & Shoot & Root & Shoot & Root & Shoot & Root & Shoot & Root & Shoot \\
\hline \multicolumn{13}{|l|}{ BF } \\
\hline Sulfur & $5.01 \mathrm{~b}$ & $1.43 b$ & $0.26 b$ & $0.08 \mathrm{~b}$ & $0.39 b$ & $0.07 \mathrm{~b}$ & $0.44 b$ & $0.14 b$ & $0.36 \mathrm{~b}$ & $0.14 b$ & $1.87 \mathrm{~b}$ & $2.82 \mathrm{~b}$ \\
\hline Gypsum & $3.72 \mathrm{c}$ & $0.41 \mathrm{c}$ & $0.23 b$ & $0.05 \mathrm{c}$ & $0.30 \mathrm{c}$ & $0.05 b$ & $0.21 \mathrm{c}$ & $0.11 b$ & $0.26 \mathrm{c}$ & $0.05 \mathrm{c}$ & $0.73 \mathrm{c}$ & $0.43 \mathrm{c}$ \\
\hline EDTA & $9.67 \mathrm{a}$ & $2.63 \mathrm{a}$ & $0.47 \mathrm{a}$ & $0.17 \mathrm{a}$ & $0.83 a$ & $0.14 \mathrm{a}$ & $0.81 \mathrm{a}$ & $0.43 a$ & $0.69 a$ & $0.26 \mathrm{a}$ & $3.59 \mathrm{a}$ & $5.63 \mathrm{a}$ \\
\hline Control & $2.34 \mathrm{~d}$ & $0.13 \mathrm{~d}$ & $0.18 \mathrm{c}$ & $0.02 \mathrm{c}$ & $0.14 d$ & $0.05 b$ & $0.17 \mathrm{~d}$ & $0.08 \mathrm{c}$ & $0.07 \mathrm{~d}$ & $0.01 \mathrm{c}$ & $0.64 d$ & $0.01 d$ \\
\hline \multicolumn{13}{|l|}{ TI } \\
\hline Sulfur & $0.28 \mathrm{a}$ & & $0.33 \mathrm{a}$ & & $0.17 b$ & & $0.32 \mathrm{c}$ & & $0.38 \mathrm{a}$ & & $1.51 \mathrm{a}$ & \\
\hline Gypsum & $0.11 b$ & & $0.22 b$ & & $0.17 b$ & & $0.57 \mathrm{a}$ & & $0.19 \mathrm{~b}$ & & $0.59 b$ & \\
\hline EDTA & $0.27 \mathrm{a}$ & & $0.37 \mathrm{a}$ & & $0.17 b$ & & $0.53 b$ & & $0.38 \mathrm{a}$ & & $1.56 \mathrm{a}$ & \\
\hline Control & $0.05 \mathrm{c}$ & & $0.15 \mathrm{c}$ & & $0.37 \mathrm{a}$ & & $0.52 b$ & & $0.10 \mathrm{c}$ & & $0.01 \mathrm{c}$ & \\
\hline
\end{tabular}

Values followed by different letters are significantly different for $p=0.05$

$\mathrm{TI}<1$ ), since a little amount of $\mathrm{Zn}$ reached the shoots (Table 2). Furthermore, the highest BF was observed in root tissues at $\mathrm{S}$ and EDTA treatments, 5.01 and 9.67 for $\mathrm{Cu}$, respectively (Table 2). Obtained $\mathrm{BF}$ values $(>1)$ for shoots at the $\mathrm{S}$ and EDTA treatments show the suitability of this plant for phytoextraction of $\mathrm{Cu}$ from sewage sludge. Unfortunately, plants do not have the ability to translate $\mathrm{Cu}$ from root to shoot $(\mathrm{TI}<1)$. BF values for shoots and roots at $\mathrm{S}$ and EDTA treatments show the usefulness of this plant in removal of $\mathrm{Pb}$ from sewage sludges. Especially at $\mathrm{S}$ and EDTA treatments, remarkable $\mathrm{Pb}$ translocations to the upper parts of the plant were observed; BF values were 2.8 and 5.63, respectively (Table 2). From the obtained TI values, plant can translate $\mathrm{Pb}$ to the upper parts at only $\mathrm{S}$ and EDTA treatments (TI $>1$ ) (Table 2). Except $\mathrm{Cu}$ and $\mathrm{Pb}$, no significant difference was found between the obtained bioaccumulation factors for the other tested metals. Maximum $\mathrm{BF}$ values were observed for $\mathrm{Cu}$ and $\mathrm{Pb}$. It was observed that $B$. juncea removed maximum amount of $\mathrm{Cu}$ and $\mathrm{Pb}$ from sewage sludge on the basis of high $\mathrm{BF}$ value for both root and shoot at EDTA and $\mathrm{S}$ treatments. Similarly, plant studied do not appear to accumulate $\mathrm{Cd}, \mathrm{Cr}$ and $\mathrm{Ni} \quad(\mathrm{BF}<1) \quad(\mathrm{TI}<1)$. Maximum transport was observed at $\mathrm{Pb}$, with a TI maximum variation ranging from 0.01 to 1.56 (Table 2). For the other heavy metals obtained in plant tissues were $<1$, indicating that the root metal concentrations were always high.

Heavy metal removal efficiencies within plant tissues

It is well known that a good phytoextraction method depends on plants producing sufficient biomass while accumulating high concentrations of heavy metals (Cui et al. 2004a, b). In the present study, the metal removal efficiencies increased with the application of S, as obtained metal concentrations at the tissues. As for $\mathrm{Pb}$ removal, the shoot removal efficiency obtained was higher than roots. In fact, it is lower at shoots for the other metals. Because of high biomass, production of $B$. juncea has excellent potential for $\mathrm{Pb}$ and $\mathrm{Cu}$ phytoextraction. Therefore, the removal of heavy metal with application of gypsum had no significant impact compared to control. The addition of EDTA had no negative effect on yield of $B$. juncea, but increased metal accumulation by $B$. juncea directly translated into equivalent increases in metal removal.

\section{Conclusion}

Results show that the addition of elemental S was a suitable strategy for the removal of heavy metals from the sewage sludge, such as an alternative to chemical amendment EDTA. Sludge $\mathrm{pH}$ decreased with $\mathrm{S}$ application and the accumulation of $\mathrm{Cu}$ and $\mathrm{Pb}$ was dramatically increased in tested plant compared to control treatment. From the results it could be concluded that $B$. juncea accumulated significantly high quantities of toxic metals in the upper parts of the plant. Overall, $65-70 \%$ of the sludge heavy metal was removed by $B$. juncea. The TI of all studied metals in shoot metal concentration/root metal concentration $(\mathrm{S} / \mathrm{R})$ was quite low ( $\mathrm{TI}<0.5)$, whereas the $\mathrm{BF}$ values were much higher in plant metal concentration/sludge metal concentration, i.e., $\mathrm{BF}$ varied from 0.01 to 9.67. Further, plant showed better $\mathrm{BF}$ for $\mathrm{Cu}$ and $\mathrm{Pb}$ metals both shoot and root. According to Ghosh and Singh (2005), a plant under accumulator category as the ratio of metal concentration in the plant to that in the soil is $>1$. From the obtained results, the efficiency to remove the $\mathrm{Cu}$ and $\mathrm{Pb}$ from sludge is high in this plant. As a result, elemental $\mathrm{S}$ when applied at the right concentration will be an effective 
amendment for the phytoextraction of heavy metals from sewage sludges' without posing any detrimental impact on the environment.

Acknowledgments This research project was funded by The Commission for Scientific Research Projects of Sakarya University (No: 06FBD36).

\section{References}

Catherine S, Christophe S, Louis JM (2006) Response of Thlaspi caerulescens to nitrogen, phosphorus and sulfur fertilization. Int J Phytoremediation 8:146-161

Cui Y, Dong Y, Li H, Wang Q (2004a) Effect of elemental sulphur on solubility of soil heavy metals and their uptake by maize. Environ Int 30:323-328

Cui Y, Wang Q, Christie P (2004b) Effect of elemental sulphur on uptake of cadmium, zinc, and sulphur by oilseed rape growing in soil contaminated with zinc and cadmium. Commun Soil Sci Plant Anal 35(19-20):2905-2916

Ghosh M, Singh SP (2005) A comparative study of cadmium phytoextraction by accumulator and weed species. Environ Pollut 133:365-371

Gupta AK, Sinha S (2007a) Phytoextraction capacity of the plants growing on tannery sludge dumping sites. Bioresour Technol 98:1788-1794

Gupta AK, Sinha S (2007b) Phytoextraction capacity of the Chenopodium album $\mathrm{L}$ grown on soil amended with tannery sludge. Bioresour Technol 98:442-446

Jiang XJ, Luo YM, Zhao QG, Baker AJM, Christie P, Wong MH (2003) Soil Cd availability to Indian mustard and environmental risk following EDTA addition to Cd-contaminated soil. Chemosphere 50:813-818

Kabata-Pendias A (2001) Trace elements in soils and plants, Third Edition, CRC Press, Boca Raton

Kalra YP, Maynard DG (1991) Methods manual for forest soil and plant analysis. Forestry Canada, Northwest Region, Northern forest Centre, Edmonton, Alberta. Information Report NORX319

Kaplan M, Orman S, Kadar I, Koncz J (2005) Heavy metal accumulation in calcareous soil and sorghum plants after addition of sulphur-containing waste as a soil amendment in Turkey. Agric Ecosyst Environ 111:41-46

Kayser A, Wenger K, Keller A, Attinger W, Felix HR, Gupta SK, Schulin R (2000) Enhancement of phytoextraction of Zn, Cd, and $\mathrm{Cu}$ from calcareous soil: the use of NTA and sulfur amendments. Environ Sci Technol 34:1778-1783
Kayser A, Schröder TJ, Grünwald A, Schulin R (2001) Solubilization and plant uptake of zinc and cadmium from soils treated with elemental sulfur. Int J Phytoremediation 3(4):381-400

McFarland MJ (2000) Biosolids Engineering, McGraw-Hill

Pierzynski GM (2000) Methods of phosphorus analysis for soils, sediments, residuals, and waters. Southern Cooperative Series Bulletin No. \# 396

Pogrzeba M, Kucharski R, Sas-Nowosielska A, Malkowski E, Krynski K, Kuperberg JM (2004) Heavy metal removal from municipal sewage sludges by phytoextraction. In: Symposium presentation

Robinson BH, Brooks RR, Clothier BE (1999) Soil amendments affecting nickel and cobalt uptake by Berkheya coddii: potential use for phytomining and phytoremediation. Ann Bot 84:689-694

Ross DS (2001) Recommended methods for determining soil cation exchange capacity. Chapter 9. University of Delaware Cooperative Extension, College of Agriculture \& Natural Resources

Ryan J, Estefan G, Rashid A (2001) Soil and plant analysis laboratory manual, 2nd edn. Jointly published by the International Center for Agricultural Research in the Dry Areas (ICARDA) and the National Agricultural Research Center (NARC). Available from ICARDA, Aleppo, Syria. x +172 pp

Samake M, Wu QT, Mo CH, Morel JL (2003) Plants grown on sewage sludge in South China and its relevance to sludge stabilization and metal removal. J Environ Sci China 15 (5): $622-627$

Singh S, Sinha S (2005) Accumulation of metals and its effects in Brassica juncea (L.) Czern. (cv. Rohini) grown on various amendments of tannery waste. Ecotoxicol Environ Saf 62:118-127

Torri SI, Lavado RS (2008) Dynamics of $\mathrm{Cd}, \mathrm{Cu}$ and $\mathrm{Pb}$ added to soil through different kinds of sewage sludge. Waste Manag 28:821-832

Turgut C, Pepe MK, Cutright TJ (2004) The effect of EDTA and citric acid on phytoremediation of $\mathrm{Cd}, \mathrm{Cr}$, and $\mathrm{Ni}$ from soil using Helianthus annuus. Environ Pollut 131:147-154

Wang AS, Angle JS, Chaney RL, Delorme TA, Reeves RD (2006) Soil $\mathrm{pH}$ effects on uptake of $\mathrm{Cd}$ and $\mathrm{Zn}$ by Thlaspi caerulescens. Plant Soil 281:325-337

Wenger K, Kayser A, Gupta SK, Furrer G, Schulin R (2002) Comparison of NTA and elemental sulfur as potential soil amendments in phytoremediation. Soil Sed Contam 11(5):655-672

Xiaomei L, Qitang W, Banks MK (2005) Effect of simultaneous establishment of Sedum alfredii and Zea mays on heavy metal accumulation in plants. Int J Phytoremediation 7(1):43-53

Xiaomel L, Qitang W, Banks MK, Ebbs SD (2005) Phytoextraction of $\mathrm{Zn}$ and $\mathrm{Cu}$ from sewage sludge and impact on agronomic characteristics. J Environ Sci Health Part A 40(4):823-838 